\title{
OBITUARIES
}

Obituaries should be submitted by email to Annabel Nicholson at annabel.nicholson@nature.com. All submitted obituaries should be 450 words maximum in length (apart from obituaries for past presidents of the BDA where the length should be 800 words).

Content of the obituary is down to the individual author, and the approval of the family should be given for the obituary prior to submission to the $B D J$.

\section{TIMOTHY LOTT}

\section{7-2014}

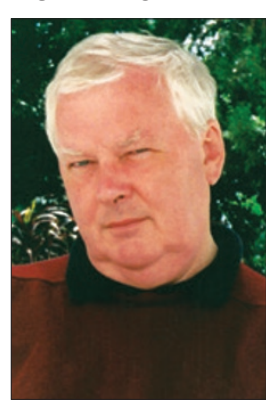

Timothy Lott was born in March 1947 and died in June 2014.

Tim was born in Whitstable, Kent and educated at Kent College, Canterbury. He obtained his BDS at Newcastle upon Tyne in 1971. On graduation he practised hospital dentistry as resident house officer for a year at Bristol Dental Hospital but after a further period as a senior house officer decided to go into general dental practice in and around Bristol. He pursued that course until his retirement in 2007.

Tim enjoyed dentistry and patients greatly but disliked the financial side of managing the 'business'. He was much admired by most of his patients for both his kind nature and his gentle and skilful treatment. In 2006, he underwent coronary artery bypass surgery but was able to return to work until he retired in October 2007.

Tim's interests were fine carpentry, classical music - especially opera - wine and France. He and his wife had a small house in the Loire Valley, which Tim loved to visit. However, all of these pursuits were restricted and curtailed by the development in early 2008 of progressive supranuclear palsy and for the last two years of his life he was completely dependent. A trip to the Loire was accomplished from April to early June 2014 but ten days after his return to the UK he died from a chest infection as a complication of the progressive supranuclear palsy.

Tim is deeply missed by his wife, Meg (née Stewardson), whom he married in 1972. At that time Meg was a fellow dental graduate but Tim supported her through a medical degree and higher training to become a consultant histopathologist, retiring in 2010 to care for Tim at home until his death. There are no children.

Meg Lott

\section{STUART TUCKER}

\section{5-2014}

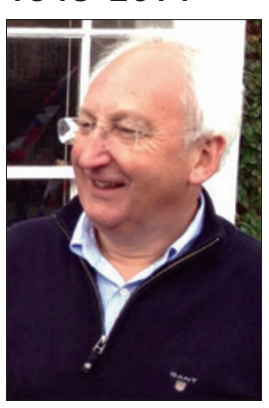

Stuart Tucker, who served the community of Southwold as a dental surgeon with great skill, integrity and kindness for over 30 years, died after a short illness on 7 September 2014. Stuart attended

Westcliff High School for Boys and qualified in dentistry from the Royal
Dental Hospital in 1968. He was an excellent student who won the Prize in Oral Medicine \&t Oral Pathology in 1967.

He had a great affinity with East Anglia. When the practice in Southwold was presented for sale in 1976, he purchased it immediately, moved into Portland House with his family and served the community to the highest standards.

Stuart was a dental surgeon who always did his best for his patients. He spent a great deal of time on postgraduate study to ensure that he kept abreast of the latest developments in dental surgery. He was a founder member of the Norwich Dental Study Group, and completed the MGDS in Advanced Dentistry from the Royal College of Surgeons in Edinburgh in 1994.

Stuart was a loving husband to Melanie and father to Nicholas. He was intelligent, kind, unassuming and unfailingly honest. He loved books and was extremely well read, having collected the entire Everyman's Library. Not content with starting an ordinary book club, he founded a reading group based on European literature. He was a member of 'The Entertainers', the most successful quiz team in the area, and was one of those people who seemed to know the answer to almost everything. His kindness, wit, intelligence and compassion will be sorely missed by family, friends, colleagues and patients alike. 